\title{
Towards The Use Of Information And Communication Technology In Undergraduates Learning: Possession, Perception And Problems In Obafemi Awolowo University, Ile-Ife, Nigeria
}

\author{
Egbedokun A.O. ${ }^{1, *} \&$ Oyewusi L.M. ${ }^{1}$ \\ ${ }^{1}$ Department of Educational Technology, Obafemi Awolowo University, Ile-Ife, Nigeria \\ *Corrreponding author: Department of Educational Technology, Obafemi Awolowo University, Ile-Ife, Nigeria. \\ E-mail: adeolaegbedokun@yahoo.com
}

Received: December 27, 2013

Accepted: March 7, 2014

Online Published: April 1, 2014

doi:10.5430/wje.v4n2p50

URL: http://dx.doi.org/10.5430/wje.v4n2p50

\begin{abstract}
This paper focuses the potentials of information and communication technologies (ICT) on three main areas as related to students learning (possession, perception and problems). It investigated students' possession, perception and problems (as envisaged or experienced) by students of Obafemi Awolowo University, Ile-Ife on the use of ICT facilities. The study employed survey method. Sample for this study consisted of 500 undergraduates randomly selected from Obafemi Awolowo University, Ile-Ife. The instrument used in this study was a 45 item likert-type questionnaire. Four objectives were formulated for the study, while simple percentages were used in data analysis. It was found that majority of the undergradutes in OAU possess ICT facilities that can be used in learning. The facilities include laptops, ipad, ipod, android phones, blackberry etc, which have capabilities for carrying instructional contents. It was also found that undergraduated perceived that these ICT facilities are useful for instructional purposes. However, they identified lack of power supply, pproblem of access, financial constrains, and phones without MMS capability as problems that might militate against the use of ICT in learning. The paper concludes that the university should harness this opportunity and use ICT facilities fully in teaching and learning.
\end{abstract}

Keywords: information; communication; technology; perception; possession; problems; integration; accessibility

\section{Introduction}

There has been much advocacy for the integration of information and communication technology (ICT) into teaching and learning in the higher institutions. This integration is expected to penetrate and bring about significant changes into the curriculum of schools, and enhance the capabilities of students at workplace after graduation. As a result of this, research in the last two decades or thereabout have focused on the integration of ICT in education. Many of these studies have reported positive effects of ICT on pupils learning (Mumtaz, 2000, Hattie, 2009; cited by Khan, Hassan and Clement, 2012). Research according to Hadad (2003) indicate that ICT can change the way teachers teach and that it is especially useful in supporting more student-centered approaches to instruction and in developing the higher order skills and promoting collaborative activities. Chickering and Ehrmann (1996) notes that the integration of ICTs in teaching and learning can advocate "good practices" in terms of encouraging active learning, giving prompt feedback, emphasising timebased tasks, communicating high expectations and respecting diverse talents and ways of learning. It is based on these findings that advocates of ICT integration into the curriculum are positive about its potency in learning as against the use of the older technologies.

Aduwa-Ogiegbaen, \& Iyamu (2005) observe that inspite of the use of old technologies such as the chalkboard, textbooks, radio/television and film in educational settings over the years, none has quite impacted on the educational process like the computer. While television and film impact on the audiovisual faculties of users, the computer is capable of activating the senses of sight, hearing and touch of the users. ICT has the capacity to provide higher interactive potential for users to develop their individual, intellectual and creative ability. The use of ICT in education has the potential for enhancing teaching methods and assessment of learning. Kulik (1994) examined 75 studies in the United States and found that students who used the following ICTs had significantly higher test scores; 
computer tutorials in mathematics, natural science, and social science. The findings also indicated that primary school students who used tutorial software in reading scored significantly higher on reading scores. Very young students who used computers to write their own stories scored significantly higher on measures of reading skill. Moreover, students who used word processors or otherwise used the computer for writing scored higher on measures of writing skill. This findings have significant consistence with the opinion of Aduwa-Ogiegbaen, \& Iyamu (2005). However, problems have always borne on the fact that these technologies have not been fully integrated into the curriculum of schools. Brosnan (2001) identified attitude, motivation, computer anxiety, and computer self-efficacy as prevailing factors affecting teachers' use of computers in their lessons. Teacher resistance and lack of enthusiasm to use ICT in education may also be another limitation working against effectively integrating ICT into schools.. Though, this is not part of the focus of this study, but it is important to note the fact.

Hennessy, Harrison, Wamakote (2010) notes that effectively introducing technology into schools is also largely dependent upon the availability and accessibility of ICT resources (e.g. hardware, software and communications infrastructure). In preparing (may be unknowingly) for this change, a large number of students of Obafemi Awolowo University have been seeing to be in possession and use of various ICT facilities. These facilities range from handheld mobile technologies to desktops and laptops. This promises hope for the integration of ICT into mainstream teaching and learning. Mwalongo (2011) believes that successful integration of ICT in the teaching-learning process, among other things, is dependent on the preparation of teachers. Teachers need not only to be prepared in terms of qualification but also in terms of instructional resources that will enhance classroom activities. Norris, Sullivan \& Poirot (2003) while concluding the results obtained from their study reamarked as follows "taken as a whole, these results refute the conventional wisdom that adoption and integration of techlnology into K-1 2 classroonms are somehow based on (or even related to) individual educator attitudes. Rather, these results indicate that teachers' use of technology for curricular purposes is almost exclusively a function of their access to that technology. This is to reiterate the opinion of Hennessy, Harrison, Wamakote (2010).

Pulkkinen (2007) opined that the growth of information and communication technologies (ICT) has dramatically reshaped teaching and learning processes in higher education. The capability of ICT for teaching and learning has grown exponentially in the last few years due to advancement in technology. This has also made technology to become the main foundation upon which the society is built. According to Daniels (2002) ICTs have become within a very short time, one of the basic building blocks of modern society. Generally, it has become a phenomenon that the industrialized world is being transformed into a knowledge-based world through ICT because information, on its own, plays a vital role in the lives of people and organizations. Goverments around the world have seen ICT as an important component to its educational development in terms of improving educational standards, widening participation in further and higher education and facilitation of lifelong learning (DfEE, 1997,DfEE,1999).

\section{Objectives of the Study}
a) Are undergraduates aware of ICT facilities?
b) What are the different ICT facilities that undergraduates of Obafemi Awolowo University possess?
c) What is the perception of undergraduates of Obafemi Awolowo University on the usability of ICT facilities in learning?
d) What are the problems with the use of ICT facilities in learning?

\section{Methods}

Sample for this study consisted of 500 undergraduates randomly selected from Obafemi Awolowo University, Ile-Ife. The instrument used in this study was a 45 item likert-type questionnaire. The research instrument is researcher designed. It has three sections: section A requires respondent to supply their bio-data. Section B contains four (4) questions which was designed to elicit response on respondent's knowledge and possession of ICT facilities. Section C contains 45 items which was used to elicit responses on (a) respondents' use of ICT facilities (b) problems of ICT, and (c) students perception of use of ICT in learning. Respondents were asked to respond to the questions in the form of SA-Strongly Agreed, A- Agreed, U-Undecided, D-Disagreed, and SD-Strongly Disagreed. Each questionnaire was handed to each respondent by both the researcher and research assistants. The researcher and the assistants went from faculty to faculty to administer the questionnaire. It was ensured that respondents attended to the questionnaire on the spot. Those who were unable to immediately attend to the questionnaire were asked to supply the researcher 
with their contacts (phone numbers or room number) and such respondents were contacted later to retrieve the filled questionnaire.

\section{Results}

Objective 1: To investigate the different ICT facilities that undergraduates of Obafemi Awolowo University possessed. To achieve this objectives, three questions were asked as shown in tables 1, 2 and 3.

Table 1. Students' Possession of ICT Facilities

\begin{tabular}{lll}
\hline Do you have ICT facilities? & Frequency $(f)$ & Percent $(\%)$ \\
\hline Yes & 420 & 93.1 \\
No & 30 & 6.7 \\
No Response & 12 & 0.2 \\
Total & 462 & 100 \\
\hline
\end{tabular}

Table 1 shows that $93.1 \%$ of students possess ICT facilities while $6.7 \%$ respondents indicated that they do not possess ICT facilities.

Table 2. The Different ICT Facilities Undergraduates of Obafemi Awolowo University Possess

\begin{tabular}{|c|c|c|c|}
\hline \multicolumn{2}{|c|}{ ICT facilities } & \multirow{2}{*}{$\begin{array}{c}F \\
36\end{array}$} & \multirow{2}{*}{$\begin{array}{c}\% \\
7.9\end{array}$} \\
\hline Valid & Laptop & & \\
\hline & Desktop & 8 & 1.8 \\
\hline & Ipad & 4 & .9 \\
\hline & Ipod & 4 & .9 \\
\hline & Blackberry & 25 & 5.5 \\
\hline & Android & 6 & 1.3 \\
\hline & Cell Phone & 152 & 33.4 \\
\hline & Laptop and Cell phone & 91 & 20.0 \\
\hline & Laptop, Cell phone and Blackberry & 38 & 8.4 \\
\hline & Laptop, Ipad, and Ipod & 4 & .9 \\
\hline & Laptop, desktop, Android and Cell phone & 17 & 3.7 \\
\hline & Ipad and Cell phone & 1 & .2 \\
\hline & Laptop and Blackberry & 22 & 4.8 \\
\hline & Ipad, Ipod, Blackberry and Cell phone & 4 & .9 \\
\hline & Blackberry and Cell phone & 8 & 1.8 \\
\hline & Laptop, Desktop, Cell phone & 3 & .7 \\
\hline & Laptop, Ipod, Blackberry, Cell phone & 2 & .4 \\
\hline & Desktop and Cell phone & 3 & .7 \\
\hline & Laptop, Ipod and Blackberry & 2 & .4 \\
\hline & Laptop, Blackberry, Android and Cell phone & 2 & .4 \\
\hline & Laptop, Ipad, ipod, Blackberry, Cell phone & 1 & .2 \\
\hline & All the listed ICT facilities & 18 & 4.0 \\
\hline & Total & 455 & 100.0 \\
\hline No res & & 7 & \\
\hline Total & & 462 & \\
\hline
\end{tabular}


Table 2 shows that $33.4 \%$ of the respondents have cell phones only, 20\% indicated that they have cell phone and laptop, while $8.4 \%$ indicated that they have laptop, cell phone and Blackberry. Also, $7.9 \%$ indicated that they have laptops and 5.5\% indicated that they have Blackberry, 4.8\% indicated that they have laptops and blackberry. The table also shows that $4 \%$ of the respondents have all these ICT facilities as listed in the questionnaire. This table generally shows that many of the undergraduates have a combination of two or more ICT facilities.

Objective 2: To find out undergraduates perception of the use of ICT facilities in learning?

This objective was achieved using a-3 point likert scale on undergraduates perception of the use of ICT facilities in learning.

Table 3. Students Perception of the Use of ICT in Learning

\begin{tabular}{|c|c|c|c|c|c|c|c|}
\hline & & \multicolumn{2}{|c|}{ A } & \multicolumn{2}{|c|}{$\mathbf{U}$} & \multicolumn{2}{|c|}{ D } \\
\hline & & $f$ & $\%$ & $f$ & $\%$ & $f$ & $\%$ \\
\hline 1. & $\begin{array}{l}\text { ICT facilities help students develop communication and } \\
\text { language skills. }\end{array}$ & 428 & 93.3 & 18 & 3.9 & 13 & 2.8 \\
\hline 2. & $\begin{array}{l}\text { ICT facilities will facilitate communication and feedback } \\
\text { between learners and lecturers }\end{array}$ & 427 & 92.8 & 20 & 4.3 & 13 & 2.8 \\
\hline 3. & $\begin{array}{l}\text { ICT facilities are needed in todays modern technological } \\
\text { world. }\end{array}$ & 437 & 96.4 & 12 & 2.6 & 4 & .9 \\
\hline 4. & $\begin{array}{l}\text { ICT facilities will encourage learners to interact and build a } \\
\text { learning community }\end{array}$ & 433 & 94.6 & 14 & 3.1 & 11 & 2.4 \\
\hline 5. & $\begin{array}{l}\text { ICT facilities will allow learners to express individuality and } \\
\text { creativity. }\end{array}$ & 425 & 93 & 19 & 4.2 & 13 & 2.9 \\
\hline 6. & $\begin{array}{l}\text { ICT facilities will allow learners to pose questions in the } \\
\text { learning community. }\end{array}$ & 405 & 88.9 & 41 & 8.9 & 12 & 2.6 \\
\hline 7. & $\begin{array}{l}\text { ICT facilities will remove the physical classroom walls } \\
\text { between learners and lecturers }\end{array}$ & 307 & 70.2 & 64 & 13.9 & 66 & 15.1 \\
\hline 8. & $\begin{array}{l}\text { ICT facilities will allow learners to become content producer } \\
\text { and not just receiver. }\end{array}$ & 378 & 86.8 & 37 & 8.5 & 20 & 4.3 \\
\hline 9. & $\begin{array}{l}\text { ICT facilities will allow learners to connect content, people, } \\
\text { ideas and conversation. }\end{array}$ & 396 & 90.6 & 33 & 7.6 & 7 & 1.6 \\
\hline 10. & $\begin{array}{l}\text { ICT facilities allow learners and teachers to share educational } \\
\text { photos and videos. }\end{array}$ & 397 & 86.5 & 39 & 8.5 & 23 & 5.0 \\
\hline 11. & $\begin{array}{l}\text { ICT facilities will allow learners and lecturers create } \\
\text { discussion or chat groups for discussion }\end{array}$ & 384 & 84.4 & 55 & 12.1 & 15 & 3.3 \\
\hline 12. & $\begin{array}{l}\text { ICT facilities will provide collaborative learning } \\
\text { opportunities and knowledge sharing. }\end{array}$ & 414 & 90.2 & 32 & 7.0 & 13 & 2.9 \\
\hline
\end{tabular}

Table 3 shows the students perception of the use of ICT facilities in learning. 93.3\% agreed that ICT facilities would help students to develop communication and language skill, 3.9\% were undecided while $2.8 \%$ disagreed. $92.8 \%$ agreed that ICT facilities would facilitate communication and feedback between learners and teachers, $4.3 \%$ were undecided while $2.8 \%$ disagreed. $96.4 \%$ agreed that ICT facilities were needed in today's modern technological world, $2.6 \%$ were the undecided and $9 \%$ disagreed. $94.6 \%$ agreed that ICT facilities will encourage learners to interact and build a learning community, 3.1\% were undecided while $2.4 \%$ disagreed. $93 \%$ agreed that ICT facilities would allow learners to express individuality and creativity, $4.2 \%$ were undecided while $2.9 \%$ disagreed. $88.9 \%$ agreed that ICT facilities would allow learners to pose questions to the learning community, $8.9 \%$ were undecided while $2.6 \%$ disagreed. $70.2 \%$ agreed that ICT facilities would remove the physical classroom walls between learners 
and teachers, $13.9 \%$ were undecided and $15.1 \%$ disagreed. $86.8 \%$ agreed that ICT facilities would allow the learners to become content producers and not just receivers, $8.5 \%$ were undecided while $4.3 \%$ disagreed. $90.6 \%$ agreed that ICT facilities would allow learners to connect content, people, ideas and conversation, $7.6 \%$ were undecided while 1.6\% disagreed. $86.5 \%$ agreed that ICT facilities allow learners and teachers to share educational photos and videos, 8.5\% were undecided while 5\% disagreed. $84.4 \%$ agreed that ICT facilities would allow learners and lecturers create discussion or chat groups for disscussion, $12.1 \%$ were undecided while 3.3 disagreed. $90.2 \%$ agreed that ICT facilities would provide collaborative learning opportunities and knowledge sharing, 7.0\% were undecided and 2.9\% disagreed.Table 4 shows that undergraduates have positive perception of ICT in learning; that ICT would facilitates thier learning. This table generally shows that undergraduates' perception of the use of ICT facilities is positive (more than $70 \%$ of respondents perceive the use of ICT facilities in learning as possible).

Objective 3: To find out the problems of the use of ICT facilites in learning.

Table 4. Undergraduates’ Identified Problems of ICT in Learning

\begin{tabular}{|c|c|c|c|c|c|c|c|c|}
\hline & & \multirow[t]{2}{*}{$\mathrm{x}$} & \multicolumn{3}{|c|}{ A } & \multicolumn{2}{|l|}{$\mathrm{U}$} & \multirow{2}{*}{$\begin{array}{l}\mathrm{D} \\
\%\end{array}$} \\
\hline & & & $f$ & $\%$ & $f$ & $\%$ & $f$ & \\
\hline 1. & Lack of power supply to charge battery & 1.79 & 385 & 85.2 & 19 & 4.2 & 48 & 10.6 \\
\hline 2. & Network problem (incessant) & 1.63 & 404 & 89.5 & 28 & 6.2 & 19 & 4.2 \\
\hline 3. & $\begin{array}{l}\text { Problems with some phones that do not have } \\
\text { MMS capabilities }\end{array}$ & 2.01 & 334 & 74 & 65 & 14.4 & 52 & 11.5 \\
\hline 4. & $\begin{array}{l}\text { Financial problems (purchase of recharge cards, } \\
\text { bundle renewal) }\end{array}$ & 1.88 & 362 & 80.5 & 45 & 10 & 43 & 9.5 \\
\hline 5. & Problem of access & 2.03 & 316 & 74.4 & 55 & 12.9 & 54 & 12.7 \\
\hline
\end{tabular}

From table 4, 85.2\% of the students agreed that lack of power to charge the battery of thier ICT facilities was a problem, $4.2 \%$ were undecided while $10.6 \%$ disagreed. $89.5 \%$ agreed that incessant network failure was a problem, $6.2 \%$ were undecided while $4.2 \%$ disagreed. $74 \%$ agreed that there are problem with some phones that do not have MMS capabilities, $14.4 \%$ were undecided while $11.5 \%$ disagreed. $80.5 \%$ agreed that financial constraints (purchase of recharge cards, bundle renewal) were a problems of the use of ICT facilities in learning, $10 \%$ were undecided while $9.5 \%$ disagreed. $74.4 \%$ agreed that the use of ICT could be limited by access to network, $12.9 \%$ were undecided while $12.7 \%$ disagreed.

Table 5. Perceived Solution to Problems of Using ICT Facilities in Learning

\begin{tabular}{llllllllll}
\hline & & $\mathrm{X}$ & \multicolumn{3}{c}{$\mathrm{A}$} & \multicolumn{3}{c}{$\mathrm{U}$} & \multicolumn{3}{c}{$\mathrm{D}$} \\
\cline { 4 - 10 } & & & $f$ & $\%$ & $f$ & & $\%$ & $\%$ \\
\hline 1. & The use of generators by faculties and departments & 1.84 & 373 & 81.8 & 45 & 9.9 & 38 & 8.4 \\
2. & Installation of more masts by service providers & 1.74 & 394 & 87.4 & 28 & 6.2 & 29 & 6.5 \\
3. & Access charge should be minimal and part of & 1.73 & 382 & 85.1 & 39 & 8.7 & 28 & 6.2
\end{tabular}
payable fees

From table 3.7, 81.8\% agreed that the problems, as identified in table 3.6 could be resolved through the use of generator by faculties and departments, $9.9 \%$ were undecided while $8.4 \%$ disagreed. $87.4 \%$ agreed that the problems could be resolved through installation of more masts by network providers, $6.2 \%$ were undecided while $6.5 \%$ disagreed. $85.1 \%$ indicated that the problems could be resolved in the sense that access charge should be minimal and part of payable fees, $8.7 \%$ were undecided while $6.2 \%$ disagreed.

\section{Discussion of the Results}

The findings of this study have revealed that undergraduates of Obafemi Awolowo University have significant knowledge of ICT facilities. This finding is interestingly not limited to knowledge of ICT facilities, they are erqually aware that these facilities could be used in facilitating learning. This finding points to the fact that integrating ICT into mainstream teaching and learning has passed "awareness contemplation". This finding is consistent with the 
findings of Adebayo and Adesope (2007). The study also revealed that undergraduates possess different kinds ICT facilities which range from handheld devices (Cell phones, Blackberry, Ipod, Ipad); laptops, and desktops. This is indicative of the fact that the road to the integration of ICT into mainstream instruction had been prepared. The fear of "not haves" is half solved because the statistics, as revealed in this study, indicates that majority of undergraduates have ICT facilities (handheld especially), that are capable of receiving instructional contents. For instance, Kolb (2011) observes that Cell phones have become mini-computers; no longer simply classroom distractions, they are now powerful classroom tools with which students can use to document science laboratories, record oral examinations, and research information. That cell phone can be used to poll students, communicate with parents, and update class blog. Android phones, for example, are becoming more and more flexible, a feature that would make them adaptable to instruction in the nearest feature. Future research should be directed into the details of the features of some of these ICT facilities and how flexible such features could be adaptable to instruction.

The study also revealed that undergraduates perceived that ICT will help them (i) develop communication and language skills, (ii) facilitate communication and feedback between them and lecturers, (iii) encourage them to interact and build a learning community, (iv) express individuality and creativity, (v) pose questions in the learning community, (vi) remove the physical classroom walls between them and lecturers, (vii) become cotent producer and not just receiver, (viii) connect content, people, and ideas (ix) create discussion or chat groups for discussion, (x) provide collaborative learning opportunities and knowledge sharing. This points are succintly stressed by Bingimlas (2009) that ICT can play various roles in learning and teaching processes. Such roles as impacting great potential to enhance student achievement and teacher learning (Bransford, 2000); playing significant part in supporting face-to-face learning in the classroom (Wong, 2006); helping students to become knowledgeable, reduce the amount of direct instruction given to them and give teachers the opportunity of helping students with particular needs or attention (Iding, Crosby and Spietel 2002; Shamatha, Peressini and Meymaris 2004; Romeo 2002). It also assist students in their learning by improving their skills, motivation, knowledge and helps in completing students learning tasks (Grabe and Grabe, 2007).

The identified problems of using ICT facilities are lack of power supply to charge battery, incessant network failure, problems with some phones that do not have MMS capabilities and financial problems. This is consistent with the findings of Adeniji, Adeniji and Oguniyi (undated) who found that that there are several problems militating against using ICT facilities in various campuses, such factors includes power outage, the high cost of connectivity, lack of ICT skills, interconnectivity problem and obsolete equipment. The above finding has established that respondents who make use of the ICT resources encounter various problems when sourcing information. This according to Okon and Nkanu (2010) are identified as infrastructural impediments to Internet connectivity and are peculiar problems that are unique to the African context (power failure, equipment failure, regulatory restriction of communication technologies, expensive or unreliable technologies and low content). Study also revealed that there are ways out of the problem. Undergraduates suggested that faculties and departments could acquire generators to power ICT facilities, network providers could install more masts in order to cover more areas and that access charges could be minimal and a part of students'payable fees.

The study also revealed that male and female undergraduates undergraduates perceive the use of ICT in the same way. This is consistent with the findings of Afolabi et al. (2005) who analyzed gender as a variable associated with the use of and attitudes about asynchronous learning networks (ALN) in a university setting. The authors found that both males and females made similar use of ALN, had similar (positive) attitudes about their computer experience, and shared a common desire to take more courses using computers.

\section{Conclusion}

This study was set out to find out what ICT facilities undergraduates of Obafemi Awolowo University have in their possession and have forund that they have these facilities in many shades. It has also found that there are potential problems that might militate against the use of these facilities in teaching and learning. It is thus recommended that the management of the university should find a way to increase the internet bandwidth in order to allow students access to the internet at no or very minimal/insignificant cost. 


\section{References}

Adebayo, E.L., \& Adesope, O.M. (2007). Awareness, access and usage of information and communication technologies between female researchers and extensionists. International Journal of Education and Development using Information and Communication Technology.

Adeniji, M.A., Adeniji, S.E., \& Ogunniyi, S. (2011). Availability and Use of ICT in Olabisi Onabanjo University Library. PNLA Quarterly, 75(3), 129-134.

Aduwa-Ogiegbaen, S. E., \& Iyamu, E. O. S. (2005). Using information and communication technology in secondary schools in Nigeria: Problems and prospects. Educational Technology \& Society, 8(1), 104-112.

Afolabi, A.O., Adedayo, Y.A., \& Adeyanju, O.L. (2005). Why College Teachers Do Not Use ICT Facilities in Teaching. Journal of E-Learn, 1(1), 25-38.

Bingimlas, K.A. (2009). Barriers to the successful integration of ICT in teaching and learning environments: A review of literature. Eurasia Journal of Mathematics, Science \& Technology Education, 5(3), 235-245.

Bransford, J., Brown, A.L., \& Cocking, R.R. (Eds) (2000). How people learn: Brain, mind, experience and school (2nd Ed.). Washington D.C.: National Academy Press.

Brosnan, T. (2001). Teaching using ICT. University of London: Institute of Education.

Chickering, AW., \& Ehrmann, SC. (1996). Implementing the seven principles: technology as lever. Retrieved 29 August 2011 from http://www.tltgroup.org/programs/seven.html

Daniels, J.S. (2002). "Foreword" in information and communication technology education-A curriculum for schools and programme for teacher development. Paris: UNESCO.

Department for Education and Employment (1997) Connecting the learning society. http://www.dfee.gov.uk/grid.connect

Department for Education and Employment. (1999). Learning to succeed : a new framework for post-16 learning. H.M.S.O.

Grabe, M., \& Grabe, C. (2007). Integrating technology for meaningful learning. (5th ed). Boston NY: Houghton Mifflin.

Haddad, W. D. (2003). Is instructional technology a must for learning? Techknowlogi.org. Retrieved, September 23, 2004,

from http://www.techknowlogia.org/TKL_active_pages2/CurrentArticles/main.asp?IssueNumber=19\&FileType=HT ML\&ArticleID=455

Hattie, J. (2009). Visible learning. Abingdon: Routledge.

Hennessy, S., Harrison D., \& Wamakote L. (2010). Teacher factors influencing classroom use of ICT in sub-saharan Africa. Itupale Online Journal of African Studies, 2(2010), 39- 54.

Iding, M., Crosby, M.E., \& Spietel, T. (2002). Teachers and technology: Beliefs and practices. International Journal of Instructional Media, 29(2), 153-171.

Khan, S.H., Hasan, M., \& Clement, C.K. (2012). Barriers to the introduction of ICT into education in developing countries: The example of Bangladesh. International Journal of Instruction, 5(2), 61-80.

Kulik, J.A. (1994).Meta-analytic studies of findings on computer-based instruction. InJ.E.L.Baker \&H.F.O’Neil (Eds.), Technology assessment in education and training. Hillsdale, NJ: Lawrence Erlbaum.

Kolb, L. (2011). Cell phones in the classroom: A practical guide for educators. USA: ISTE.

Mumtaz, S. (2000). Factors affecting teachers' use of information and communications technology: A review of the literature. Journal of Information Technology for Teacher Education, 9(3), 319-342. http://dx.doi.org/10.1080/14759390000200096

Mwalongo, A. (2011). Teachers' perceptions about ICT for teaching, professional development, administration and personal use. International Journal of Education and Development using Information and Communication Technology (IJEDICT), 7(3), 36-49.

Norris, C., Sullivan, T., \& Poirot, J. (2003). No access, no use, no impact: Snapshot surveys of educational technology in K-12. Journal of Research on Technology in Education, 36(1), 15-27. http://dx.doi.org/10.1080/15391523.2003.10782400 
Nkanu, W.O., \& Okon, H.I. (2010). Digital Divide: Bridging the Gap through ICT in Nigerian Libraries. Library Philosophy and Practice, 2010.

Pulkkinen, J. (2007). Cultural globalization and integration of ICT in education. In K. Kumpulainen (Ed.), Educational technology: Opportunities and challenges (pp. 13-23). Oulu, Finland: University of Oulu.

Romeo, G.I. (2006). Engage, empower, enable: Developing a shared vision for technology in education. In M.S. Khine (ed) Engaged learning and Emerging Technologies, The Netherlands: Springer Science. http://dx.doi.org/10.1007/1-4020-3669-8_8

Shamatha, J.H., Peressini, D., \& Meymaris, K. (2004). Technology-Supported mathematics activities situated within an effective learning environment theoretical framework. Contemporary Issues in Technology and Teacher Education, 3(4), 362-381.

Wong, A.F.L., Quek, C.L., Divaharan, S., Liu, W.C., Peer, J., \& Williams, M.D. (2006). Singapore students' and teachers' perceptions of computer-supported project work classroom learning environments. Journal of Research on Technology in Education, 38(4), 449-479. http://dx.doi.org/10.1080/15391523.2006.10782469 